\title{
WILLIAM MARSDEN ALS BEOEFENAAR DER TAALWETENSCHAP.
}

DOOR

J. GONDA.

William Marsden, bij de beoefenaars van het Maleis wel bekend door z'n History of Sumatra en z'n door lateren geprezen, bij ons door Elout vertaalde grammatika en z'n eveneens vertaalde woordenboeken, heeft, afgezien van enkele grotere werken op ander gebied, bovendien enkele kleinere taalkundige verhandelingen gepubliceerd, die, naar het mij voorkomt, ten onrechte wat in vergetelheid geraakt schijnen. $\mathrm{Nu}$ het onlangs 100 jaar geleden was, dat hij overleed, grijp ik deze gelegenheid, zij het wat laat, aan on op enkele zijner verdiensten te wijzen.

Geboren 16 Nov. 1754 te Verval, Ierland, als zoon van een directeur van de National Bank of Ireland, uit een van origine Engels geslacht, en aanvankelijk voor het geestelijk ambt bestemd, trad hij op aansporen van een broer in dienst van de East India Company (1770) en was tot 1779 als secretaris te Benkoelen werkzaam. Na zijn repatriering kon hij veel tijd besteden aan wetenschappelijk werk, hoewel hij van 1795 tot 1807 de zeer gewichtige positie van (eerst second, daarna first) secretary of the admiralty bekleedde. Hij was sinds 1807 gehuwd met een dochter van Charles Wilkins en stierf 6 Oct. $1836^{1}$ ).

Marsden was een van de vele Engelsen die ten tijde van Hastings' optreden in Indië (1772-1785) en daarna niet alleen op staatkundig terrein, althans in een publiek ambt, maar ook op dat der wetenschap, hun vaderland dienden, die in het Oosten hun plicht deden als bestuurders, doch tevens een open oog hadden voor de talloze merkwaardigheden die natuur, samenleving en cultuur daar boden,

1) Uitvoeriger: Dictionary of national biography, ed. by Sidney Lee, vol. XXXVI (London 1893), p. $206 \mathrm{vlg}$. Zie ook: A brief memoir of the life and writings of the late William Marsden... written by himself, London, 1838, 177 bldzz., for private circulation only, uitgegeven door zijn weduwe (interessante lectuur). 
die staande in de volle realiteit, de enorme waarde van wetenschappelijke beoefening van die maatschappelijke en culturele verschijnselen voor de duurzame vestiging van het Engelse bewind begrepen. Hastings zelf, de grootste der Engelse bestuurders over Indië, paarde, als Akbar, aan een groot organisatietalent belangstelling voor en beoefening van velerlei wetenschappen; bekwaam in Perzisch, Bengali en andere inheemse talen, kenner van natuurlijke historie, geografie en kunst, bevorderaar van de studie van het inheemse recht, steeds trachtend de inheemse cultuur te begrijpen: „No Englishman ever understood the native character so well as Hastings". Hij kan worden beschouwd als de grondlegger van het Brits-Indische bestuurssysteem, maar ook werd op zijn instigatie door Jones, ,de Justinianus van Indië", de Asiatic Society (later: of Bengal) gesticht (1784), waarin de studie van het Sanskrit en de Indische cultuur een middelpunt vonden, studie die voor 'n groot deel in handen lag van rechters, bestuursambtenaren, artsen, officieren, die hun vrije tijd aan de wetenschap wijdden; Jones was rechter, Colebrooke, de grondlegger van de Sanskrit-filologie, bekleedde verschillende bestuursfuncties, Wilkins ,le premier Européen peut-être qui ait vraiment su le sanscrit” ${ }^{1}$ ), de ,Sanscrit-mad gentleman” (1750-1836), de iets oudere vriend en later schoonvader van Marsden, was ,a writer in the East India Company's Civil Service”. Marsden, die op de jeugdige leeftijd van nog geen 16 jaar z'n schoolopleiding had afgebroken om naar Benkoelen te gaan, besteedde daar z'n vrije tijd behalve aan toneelspelen, vertalen uit 't Grieks en dichten aan bevrediging van z'n weet- en leergierigheid ${ }^{2}$ ), later ook aan 't verzamelen van bouwstoffen voor z'n werk over Sumatra. Door omgang met de bevolking en verhoor van verdachten, studie van brieven, godsdienstige en ",rechts”-geschriften en ,heroic romances”, bekwaamde hij zich in 't Maleis ${ }^{3}$ ).

1) A. Barth, in Journal des Savants, 1900 , p. 119.

2) Autobiografie, pp. 11 vlgg. „I had an ardent thirst for knowledge”, „my curiosity being ever awake to the novelty of objects around me".

$\left.{ }^{3}\right)$ Over inlandse leermeesters spreekt hij niet. Abdoellah, Autobiografie, pp. 7 vlg. K1. vertelt, dat 'n toean Marsden bij zijn vader gedurende één jaar en 8 maanden in Malakka les had genomen; op gezag van den zendeling Thomsen deelt hij daar mee dat dit de auteur van het Mal.-Eng. Woordenboek Marsden was. Wat algemeen aangenomen schijnt: Klinkert, Aant. op de Hik. Abd.. Leiden 1882, p. 10; Van der Linden, De Europeaan in de Mal. Lit., Diss. Utr. 1937, p. 239. Uit Marsden's autobiografie, die bij reizen en derg. gaarne stilstaat, wordt evenwel over 'n oponthoud in Malakka niet gesproken: hij is er voorzover mij bekend niet geweest. 
$\mathrm{Na}$ zijn terugkeer in Engeland veel verkerend in kringen van beoefenaars der wetenschap, lid van de Royal Society en verscheidene andere geleerde genootschappen, voortdurend aan 't verzamelen van grammatika's, woordenboeken, Oosterse munten, zeer veel op reis, trad hij in Febr. 1781 voor de Society of Antiquaries op met z'n voordracht over de talen van Sumatra ${ }^{1}$ ), publiceerde 1783 z'n bekende History of Sumatra, en in 1785 'n verhandeling over de taal der Zigeuners ${ }^{2}$ ). „This was the first notice that had appeared in England of the Indian origin of this extraordinary race, and which had been suggested to me by accidentally meeting with a short list of their words (vocabula Cingarorum), in ,Ludolfi Commentario in suam Historiam Aethiopicam" ${ }^{3}$ ) which struck me as being Hindustani. A German work on the same subject, as I afterwards found, had been published by Grellman ${ }^{4}$ ) in the preceding year; but this was entirely unknown to me, as well I believe as to other English readers" ${ }^{5}$ ). In $z$ 'n kleine verhandeling over de taal der Zigeuners vatte hij het onderwerp wetenschappelijk aan: hij onderzocht eerst of de taal die de Gypsies in Engeland spraken werkelijk dezelfde was als die van de Zigeuners van het Continent. Toen dit het geval bleek te zijn, trachtte hij (op grond van 'n vergelijking van 39 woorden) vast te stellen dat deze taal met het Hindustani samenhing. Het onderzoek baarde verrassingen:, it is not a little singular that the terms for the numerals 7, 8 and 9 are purely Greek". In dit opstelletje wijst hij er o.a. op hoe voorzichtig men moet zijn met op 't gehoor af opgetekend taalgoed van weinig bestudeerde talen, ,for the dissimilar manner in which the same individual sound strikes the organ of the hearers".

In 1789 had hij al plannen voor z'n werken over de Maleise taal:

1) Autobiografie, p. 49. Zie beneden.

2) ;Observations on the Language of the People commonly called Gypsies, in a Letter to Sir Joseph Banks", in Archaeologia, ed. by the Society of Antiquaries, VII.

3) De beroemde Job Ludolf (1624-1704), de grondige kenner van het Aethiopisch en der Semietische talen in 't algemeen.

4) Hij bedoelt H. M. G. Grellmann, Die Zigeuner, 1783, vooral in de Franse vertaling zeer bekend geworden (1810) : „Histoire des Bohémiens”. (Vgl. Ratzel in Allg. deutsche Biographie der kg. bayer. Ak. d. Wiss., dl. 9, p. 636/7). Woordenlijst en vergelijking in G.'s boek zijn van Büttner afkomstig, die „so gut wie gar keine Einsicht in das Zigeuneridiom besasz" (Pott, Die Zigeuner, I, 1844, p. 14). 't Eerst schijnt de Indische herkomst van de Zigeunertaal door J. C. C. Rüdiger gevonden te zijn (1777); vgl. Pott, t.a.p., p. 13; Leskien, in Allg. deutsche Biogr. 29, p. 468.

5) Autobiografie, p. 61. 
„The first work ... I should wish to publish, is the Malay Dictionary, with a Grammar (not yet begun)" ${ }^{1}$ ), waarvoor hij zich o.a. met de lectuur van de door Nederlanders bezorgde Maleise vertaling van Oude en Nieuwe Testament bezig hield, ,but this being the work of Europeans, I do not venture to adopt any term, or any unusual sense of a term, unless I find it corroborated by the authority of native manuscripts, \&c." ${ }^{2}$ ). Gelijk bekend verschenen deze werken in $1812^{3}$ ). Over z'n numismatische en andere publicaties ${ }^{4}$ ) en $z^{\prime} n$ overige verdiensten spreek ik hier niet.

Ook z'n betoogje over de invloed van het Sanskrit op het Maleis, waaraan hij tegelijk met Jones ${ }^{5}$ ) z'n aandacht wijdt, is nog het lezen waard ${ }^{6}$ ). Deze talen moeten ,,intercourse” gehad hebben waarschijnlijk wel verscheiden eeuwen voordat de Maleiers Mahommedaan werden. „The Hindu words , .. are such as the progress of civilization must soon have rendered necessary...., „It is not however to be understood, that the affinity between these language is radical". „The marks of cultivation by which the Malayan is distinguished from his ruder neighbours, are to be attributed in my opinion, to

1) Uit een brief, zie Autob., p. 72, n.

2) Uit een brief, 1792 , ibid., p. 81 , n.

$\left.{ }^{3}\right)$ „The impression was large, and, unfortunately for my labours, the extensive possessions conquered from the Dutch, where the Malayan is spoken, were gratuitously restored to them, and my sale contracted", Autob. p. 144. Aldaar ook 'n oordeel over deze werken en de Hist. of Sum. - die evenals z'n overige werken ook bij andere tijdgenoten 'n zeer goede naam hadden -, van Von Humboldt: „Il serait impossible d'exposer les resultats de recherches plus savantes, plus profondes, et plus solides, avec plus de clarté, d'élégance, et de méthode" (Brief van 2-4-1831). Men verzuime echter niet het oordeel van Van der Tuuk, Aant. Bat. Leesb., pp. 110 vlg., te lezen.

4) Numismata Orientalia illustrata, described and historically illustrated, 2 dln.; The Travels of Marco Polo, with notes, etc.

5) Vgl. Asiatic Researches III, pp. 8 vlgg., en IV, 227. In deze 8e jaarlijkse voordracht, gehouden 24-2-1791, „On the borderers, mountaineers, and islanders of Asia”, pp. 1-16, zegt hij p. 9: „from the very accurate and interesting account of it by a learned and ingenious member of our own body, we discover, without any recourse to etymological conjecture, that multitudes of pure Sanscrit words occur in the principal dialects of the Sumatrans.... If Mr. Marsden has proved (as he firmly believes, and as we, from our knowledge of his accuracy, may fairly presume) that clear vestiges of one ancient language are discernible in all the insular dialects of the southern seas from Madagascar to the Philippines, and even to the remotest islands, lately discovered, we may infer from the specimens in his account of Sumatra, that the parent of them all was no other than the Sanscrit..." (pp. 9, 10). Een voorloper van het zo weinig succesvolle denkbeeld van Bopp! (Zie mijn opstel Taalbeschouwing en Taalbeoefening).

6) On the traces of the Hindu language and literature, extant amongst the Malays, Asiatic Researches IV (1799), pp. 221-227. 
the effects of an early connexion that must have subsisted between the inhabitants of this eastern petinsula and those of the continent of India". Hò is moeilijk te zeggen, maar : , a spirit of foreign conquest, and still more, a zeal for the propagation of their religious tenets, appear incompatible with the genius of the Hindu system..." 1).

Als handel de Sanskrit woorden naar de Archipel gebracht heeft, "I should be inclined to consider the people of Guzerat, notwithstanding their distance, as the instructors of the Malays" ${ }^{2}$ ). Hij geeft dan de volgende woorden op als leenwoorden uit Indië: soeka, soeka-tjita, doeka, bagi, bangsa, basa, bitjara, bidji, boedi, loba, djaga, poeteri, rata, poernama, tjari. Er zijn na hem wel minder juiste lijstjes gepubliceerd! Met John Leyden is hij het eens dat de leenwoorden niet door het Pali in het Maleis gekomen zijn ${ }^{3}$ ). Hij bestrijdt diens opvatting dat Tamil c.s. het Maleis "heeft verbeterd" en ziet in, dat het verkeerd is de Dravidische talen, zoals men veelal deed, van het Sanskrit af te leiden ${ }^{4}$ ).

Uit Marsden's taalkundige werken blijkt 'n diepgaande belangstelling, een opmerkingsgave, 'n heldere geest, nuchterheid, 'n grote mate van gezond verstand, onpartijdigheid, een voor zijn tijd opmerkelijk degelijke betoogtrant. Hij bleef met z'n benen op de grond en verloor zich niet in vage theorieën. Menige passage uit zijn werk is voor dengeen die gewend is aan wat een eeuw later over de Maleise taal is geschreven een verademing.

Z'n eerste werk, op 26 jarige leeftijd voorgedragen is reeds zeer belangrijk ${ }^{5}$ ). Gelijk bekend heeft Von Humboldt lang als de eerste gegolden die de verwantschap tussen de "Maleisch-Polynesische" talen heeft aangetoond, totdat, voorzover mij bekend door Schmidt $^{6}$ ), er op is gewezen dat reeds voor hem Hervás ,,deze taalfamilie ontdekt had", wat door anderen, o.a. door mij zelf ${ }^{7}$ ) is overgenomen. Het blijkt echter duidelijk uit dit met 5 Maart 1780 ondertekende geschrift van Marsden, dat deze reeds enige jaren voordat de boeken van Hervás verschenen (1784 vlgg.) dezelfde gedachte heeft

\footnotetext{
1) p. 222 .

2) Vgl. ibid., pp. LX vlgg.

3) Mal. Spraakkunst, Inl. (vert.), p. L.

4) Vgl. ibid., p. LVIII.

5) Remarks on the Sumatran Languages, Archaeologia (zie boven), d1. VI, London 1782, pp. $154-158$.

6) P. W. Schmidt, Die Sprachfamilien und Sprachenkreise der Erde, pp. 30,141 .

7) Gonda, Austrisch en Arisch, Inaug. rede, Utrecht, 1932, p. 6.
} 
uitgesproken ${ }^{1}$ ). Reden waarom deze korte verhandeling een uitweiding rechtvaardigt. Twee lijsten van woorden vergezellen het in de vorm van een brief aan Sir Joseph Banks ${ }^{2}$ ), President of the Royal Society, „munificent patron of science” geklede artikel, waarvan „the one exhibits simply a list of fifty words; of universal use from the nature of the ideas they express; as spoken in twelve different countries or districts", 't zijn de telwoorden 1-10, 100, woorden voor familierelaties, lichaamsdelen, enkele kleuren en elementen etc. in English „Malay, Acheen, Batta, Lampoon, Neeas, Rejang, Javan, Malagash, Mongeraye, Macassar, Savu, Otaheite en Chinese"; de laatste taal telt echter evenmin als 't Engels natuurlijk, tot het 12-tal. „The other exhibits a view of those words in the Sumatran and neighbouring languages, which are observed to correspond in sound and signification, with words in the languages of places situated at a distance from thence”. ,My chief design in these collection, was to trace, if possible, a common origine ${ }^{3}$ ). My secondary object, to

1) Crawfurd, in de Dissertation, voorafgaande aan z'n Malay Grammar, p. 2, met noot, stelt het zo voor, dat J. R. Forster, de Duitser die de tweede reis van Cook (1772-1775) meemaakte (vgl. bv. Allg. Deutsche Biogr., 7, 169 vlgg.), eigenlijk de vader van deze gedachte geweest is. Hij citeert daartoe uit „Voyage round the World", van z'n zoon G. F., London 1778, o.a., dat we een opmerkelijke gelijkenis tussen woorden uit de Zuidzee en enkele Maleise vinden. „But it would be highly inconclusive, from the similarity of a few words, to infer that these islanders were descended from the Malays", waarom hij vermoedt ,that all (d.w.z. inclusief 't Maleis?) these dialects preserve several words of a more ancient language, which was more universal and was gradually divided into many languages". De met Maleise woorden identieke uit talen der Zuidzee bewijzen hem ,that the South Sea isles were originally peopled from the Indian, or Asiatic Northern isles; and that those lying more to the westward received their first inhabitants from the neighbourhood of New Guinea". In M.'s Bibl. Marsdeniana ontbreekt dit werk van Forster. Het komt mij echter volstrekt ongeloofwaardig voor dat $\mathrm{M}$. de inhoud van dat werk niet gekend zou hebben: als hoofdmotief voor zijn repatriering uit Sumatra geeft hij zelf op z'n vurig verlangen om te Londen in geleerde kringen de uitkomsten van de wereldreizigers te leren kennen (Autob., pp. 25 vlg.); bovendien, dat onder de onderwerpen van gesprek met Banks e.a. de talen van de „Eastern and South-sea Islands" behoorden (ibid., p. 47), waarbij: „, and as I had formed a collection of a number of dialects for the purpose of comparison, I addressed to him a short treatise". M. geeft echter op enkele plaatsen voorgangers (Grellman, Werndly, Heurnius) alle eer en zou m.i. hier Forster vermeld hebben als hij aan hem ontleend had. Bovendien is er verschil tussen de vage visie van F. en M.'s standpunt. Dat invloed van boek of denkbeeld van F. evenals de gesprekken met vrienden $\mathrm{M}$. stimuleerden en hem er toe brachten zijn mening te publiceeren lijkt me dus 't waarschijnlijkste. Ik heb het citaat in het uitvoerige, registerloze werk van F. niet nagespeurd.

2) Zie over hem Dictionary of national biography, vol. III, pp. 129 vlgg.

3) Vgl. ook de Inleiding op z'n spraakkunst, Marsden-Elout, pp. XXXVI vlg. 
determine whether the various independent and unconnected nations who inhabit the internal parts of Sumatra, speak languages radically and essentially different, as is generally supposed by the Europeans resident there, or only different dialects of the same". In 't eerste opzicht heeft hij weinig resultaat gehad, zegt hij, ,perhaps from want of sufficient opportunity of acquaintance with the continental tongues”. „It may possibly then be found that Tartary, that great officina gentium, has supplied the south eastern archipelago with inhabitants. A knowledge of the original Siamese, Laos Cambodian and Peguan languages, as these nations lie in the intermediate space, would present the readiest clue to a discovery of that kind. But here I am in the dark". Wie denkt hier niet aan het stamland der MaleisPolynesische taalfamilie door Kern en Kuhn in Achter-Indië gezocht, in Campā, Cochin-China, Kambodja (1889) en aan Schmidt's „Mon-Khmer-Völker, ein Bindeglied zwischen Völkern Zentralasiens und Austronesiens" (1906) ? ${ }^{1}$ ).

Marsden heeft behalve bij 't „Savu and Otaheite” z'n woorden uit de mond der inheemsen, niet uit boeken. Z'n conclusie is ${ }^{2}$ ): „The only general inference we can draw on this head, is, that from Madagascar eastward to the Marquesas, or nearly from the east coast of Africa to the west coast of America, there is a manifest connexion in many of the words by which the inhabitants of the islands express their simple ideas, and between some of the most distant, a striking af finity".

„Velen zullen in de talen van Sumatra slechts dialektverschillen zien”, maar Marsden zelf is ,far from thinking the general resemblance so decided as to put the point beyond dispute". Hij betoogt $\mathrm{nu}$, dat de omstandigheid dat de verschillende Sumatraanse talen niet allen hetzelfde alfabet bezitten aan sommigen zou schijnen te bewijzen, ,that their origins were unconnected" en dat de onderlinge gelijkenis zou zijn veroorzaakt door 't overnemen van leenwoorden. „It is certain that they conceive thus of themselves; that they do not in the least comprehend each other's discourse. But on the other hand it will be argued that the resembling or common words are radical and such whose correspondent ideas must have existed and been described prior to all intercourse with either remote or neighbouring people”. „The dissimilarity, not the similarity, must have been induced by degrees”. Hij betoogt dan de waarschijnlijkheid, dat ,this

1) Over een en ander Gonda, t.a.p., p. 7 vlgg.

2) p. 155 . 
art of representing our thoughts by visible signs took its rise among these people after the period of their separation". We hebben hierbij te bedenken, dat in de XVIIIe eeuw beschouwingen over het alfabet en het schrift tot het terrein van de taalwetenschap en de grammatika behoorden.

Om de samenhang van de woorden van z'n tabellen na te gaan moet men weten dat ,there are several letters or simple sounds, which, though to our organs they seem distinct, are often confounded and transposed in rude languages". Zo wordt eedong (hidoeng) in 't Maleis, eerong (iroeng) in 't Javaans. „The letters usually confounded are $\mathrm{L}$ and $\mathrm{R}, \mathrm{P}$ and $\mathrm{F}, \mathrm{D}$ and $\mathrm{T}, \mathrm{D}$ and $\mathrm{R}, \mathrm{B}$ and $\mathrm{V}$, Oo and R”. „Confounded”, maar toch reeds een „Ahnung” van de $\mathrm{D}-\mathrm{L}-\mathrm{R}$ wisseling. Over de $f$ in 't Nias spreekt hij ook in z'n History of Sumatra.

Hij eindigt met te waarschuwen tegen 't hechten van 'n grote waarde aan de zeer vergaande overeenkomst in de telwoorden; hij is van mening dat deze niet kan worden beschouwd als een ,presumptive proof" voor een gemeenschappelijke origine van de volkeren die ze gebruiken. "Counting, however simple a business it may appear to us... is matter of science", en ,is zeer waarschijnlijk niet alle volkeren van 't begin af eigen geweest". ,Men may exist long together without finding it absoluty necessary to express these ideas". Inderdaad zijn er (bv. in Zuid-Amerika, Australië etc.) verscheiden ,primitieve volkeren” in wier dagelijks leven het tellen een zeer geringe rol speelt en die vaak geen hogere telwoorden dan „twee” of „drie" kennen ${ }^{1}$ ).

Voor de woordenlijsten zelf mag ik naar 't origineel verwijzen. Enkele opmerkingen slechts: Dat hij behoorlijk heeft waargenomen en weergegeven blijke bv. uit de telwoorden van 't Nias (men houde natuurlijk rekening met z'n Engelse transcriptie): sembooa, dembooa, tuloo, oopha, leema, oonoo, pheetoo, ooalloo, seewa, phooloo. Blijkens 8: slappan, head: capallo, good: baye etc. geeft de kolom „Malay” Minangkabaus. Onder de woorden die in de kolom „Makassaars" staan zijn verscheiden Boeginese; hoe kon 't anders? Bv. één : saydee (Boeg. sêdi, Mak. sêre), 7: peetoo (Boeg. pitoe, Mak.

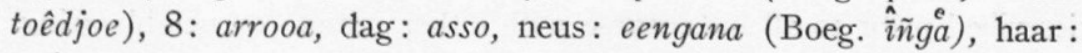

1) Vgl. bv. Lévy-Bruhl, Les fonctions mentales, pp. 204 vlgg.; Cassirer, Philosophie der symbolischen Formen I, pp. 186 vlgg.; P. W. Schmidt, Die Sprachfamilien und Sprachkreisen der Erde, p. 358; Olbrechts, Ethnologie, pp. $76 ; 259$. 
gummanna, etc.; in de twee laatstgenoemde gevallen en elders heeft hij -na (van hem, etc.) tot het substantief gerekend. Voor 't Atjehs geeft hij tloo voor 3, d'lappan voor 8. Bat. „vis” is dekkay (immers uit de mond opgetekend), zwart: nabeerong, waarin 't ,relativum $n a$ ". Etc.

De tweede tabel draagt het opschrift „Examples of words in the Sumatran and Neighbouring Languages corresponding in sound and signification with others in places remote from thence", en bevat 28 woorden, telkens in 2-15 verschillende talen, en wel afzonderlijk „Sumatraanse” èn Javaans tegenover ver verwijderde als Otaheite, Garageeco, Madagascar, Bugguess or Macassar, Savic Easter island, Marquesas, Malicolo; echter ook N. Zealand, N. Caledonia, Chinese. Z'n materiaal is uiterst gering en er staan onjuistheden in, doch welk van dergelijke verzamelingen van lateren is geheel feilloos? Op het principe komt het hier aan.

In z'n History of Sumatra ${ }^{1}$ ) spreekt hij over dezelfde kwestie: de verschillende talen van dat eiland zijn duidelijk verwant, maar niet alleen onderling, ,also to that general language which is found to prevail in, and to be indigenous to all the islands of the eastern sea, from Madagascar to the remotest of Captain Cook's discoveries" "2). Weliswaar is hier en daar vermenging en ,bederf” opgetreden, „but between the most dissimilar branches an evident sameness of many radical words is apparent", en dat ook in ver van elkaar verwijderde streken ,as for instance the Philippines and Madagascar". Men denkt onwillekeurig aan Brandstetters „Tagalen und Madagassen”. Hij wenst dit dan uit te breiden tot een beschouwing van alle talen in de wereld onder dit gezichtspunt. Er volgt o.a. nog 'n lijst van 37 woorden in „Malay, Achin, Batta, Rejang, Lampong” ${ }^{3}$ ). Ook herkent hij in het ,inheemse", niet Arabische, Sumatraanse alfabet invloed van dat van 't Sanskrit ${ }^{4}$ ). 't Bataks, zegt hij elders ${ }^{5}$ ), schijnt minder veranderingen ondergaan te hebben dan vele verwante talen: 't heeft met de talen van Java, Celebes en de Philippijnen veel gemeen met 't Malagasi, ,being all, in my judgment, from one common stock". Gelijk bekend is men tegenwoordig van mening, dat vergelijking van Toba-Bataks, Javaans en Tagalok de beste grondslag levert

1) 3e ed. 1811, p. 200.

2) Diens expeditie en resultaten hadden in Marsden belangstelling voor deze zaken gewekt: Autobiografie, p. 151.

3) p. 203.

4) p. 201; vgl. ook Asiatic Researches, IV, p. 225 ,tot Celebes toe”.

5) p. 382 . 
om zo volledig mogelijk het klanksysteem van de Indonesische oertaal te leren kennen ${ }^{1}$ ). Marsden had wel een gelukkige intuitie! Elders ${ }^{2}$ ) voegt hij er aan toe, dat het „Polynesisch” niet de taal is van de Papoea en Semang, die evenals de „Haraforas” e.a. van ander ,geslacht” een ,even belangrijk als moeilijk punt van onderzoek" zouden opleveren.

Ik zei reeds dat Marsden een verzameling aanlegde van taalkundige werken, waaraan hij veel te koste legde: „the expense ruins $m e^{\prime 3}$ ). Ook maakte hij een catalogus van alle bekende woordenboeken en grammatika's van minder bekende talen, die veel uitgebreider werd dan hij verwacht had $\left.{ }^{4}\right)$. Van zijn eigen boeken liet hij, oud geworden, een mooi uitgevoerde catalogus drukken en aan vrienden en bibliotheken ten geschenke geven: een werk van 309 bladzijden in 2 kolommen ${ }^{5}$ ). De kostbare verzameling van vooral XVIe, XVIIe en XVIIIe eeuwse taalkundige werken, reisbeschrijvingen etc. schonk hij voor z'n overlijden aan King's College Londen. Waarom tengevolge van deze belangstelling voor taalwetenschap en na en naast $z$ 'n verdienstelijke taalkundige werken geen groot samenvattend werk uit $z^{\prime} n$ pen gevloeid is, zet hij zelf uiteen ${ }^{6}$ ). Hoewel ,the comparison of languages including etymology" door vrienden als zijn studiegebied werd beschouwd, en hij ook als materiaalverzameling voor 'n groot werk woordenlijstjes liet verspreiden ter invulling door ,intelligent travellers" om dan voor iedere afzonderlijke taalgroep te komen tot een structuuranalyse, ,, a brief analysis of (the) structure" en ,to point out (the) peculiarities of idiom, as well as its analogy, more or less remote, to other tongues", zag hij toch na het verschijnen van de op instigatie en met medewerking van keizerin Catharina van Rusland tot stand gekomen Linguarum Totius Orbis Vocabularia comparativa, de „Vocabularia Petripolitana”, van Pallas (1786-7) en van de werken van Hervás en Adelung-Vater ${ }^{7}$ ) van z'n plan af, ofschoon, voegt hij er aan toe, „I might still have flattered myself with the expectation of producing a more extensive comparison, as

1) Vgl. bv. Dempwolff, Vergl. Lautlehre, 1934, p. 24.

2) Mal. Gramm., zie Marsden-Elout, p. XLII.

3) Brief 1790, Autobiografie, p. 77, n.

4) Vgl. ibid., p. 71, n. Gedrukt in 60 exx. en niet verspreid (1796).

5) Bibliotheca Marsdeniana philologica et orientalis. A catalogue of books and manuscripts collected with a view to the general comparison of languages, and to the study of oriental literature, by William Marsden, London, 1827.

6) Autobiografie, pp. 150 vlgg.

$\left.{ }^{7}\right)$ Hierover elders. 
well as of more practical utility". Tenslotte ook, ,the object of the public is novelty; the most successful writers being those who indulge in fanciful theories". Hij publiceerde nog slechts een kleirı stukje over het Siwah ${ }^{1}$ ).

Zijn opmerkingen over de eigenaardigheden van het Maleis die hij behalve in z'n aan de taal gewijde werken ook op enkele plaatsen in de History of Sumatra behandelt bespreek ik in ander verband ${ }^{2}$ ). Evenzo zijn verhandeling, „On the Polynesian, or East-insular languages”, die zich beter samen met het werk van Crawfurd e.a. laat bezien. Deze verhandeling, reeds vroeger geschreven, maar in 1832 uitgewerkt ${ }^{3}$ ), verscheen in $1834^{4}$ ), tezamen met twee kortere, waarvan de eerste „On a conventional roman alphabet applicable to oriental languages" wederom blijken van de praktische zin van den auteur geeft. Al zijn in deze pennevrucht, uit den aard der zaak - we treffen bij de grondleggers van de moderne taalwetenschap in die tijd dezelfde aan - misvattingen aan te wijzen, het stuk geeft blijk van goed nadenken; het door hem o.a. voor het Maleis voorgestelde transcriptiesysteem, waaruit de c-aileen gebannen, de $\mathrm{u}=\mathrm{u}$ (oe) en twee letters voor één ,,articulatie" zoveel mogelijk worden vermeden, is echter door z'n landgenoten niet nagevolgd. Op p. 7 blijkt dat hij 't verschil tusschen kwantiteit en akoustische kleur van 'n vokaal duidelijk zag, nog heden geen gemeengoed. De derde verhandeling uit de genoemde bundel "On the composition of a national English dictionary" leert ons dat Marsden voorstander was van een praktisch-normatief woordenboek naast een wetenschappelijk, èn naast een etymologisch lexikon ${ }^{5}$ ); door samenwerking onder eenhoofdige leiding van "qualified persons" onder patronage van 'n bevoegd lichaam, met extra-hulp van deskundigen voor de slechts ten dele op te nemen ,technische woorden” dient een woordenboek tot stand te komen.

Marsden behoorde tot de generatie van Jones en Wilkins, de voorgangster van die welke de Indogermanistiek en daarmee de XIXe eeuwse taalwetenschap zou grondvesten; niet als zijn tijdgenoten aan

1) In Proc. of the Association for promoting the Discovery of the Interior parts of Africa, II, II, pp. 209-212, London, 1802.

2) Taalbeschouwing en Taalbeoefening.

3) Autobiografie, p. 168.

4) Miscellaneous works.

5) $\mathrm{Hij}$ pleit, p. 7, n., voor een onderzoek naar 't niet uit 't Latijn afkomstige deel van de Franse woordschat; p. 10 voor grote aandacht te besteden aan de accentuatie. 
de eerste beoefening van het Sanskrit, maar aan de voortzetting en verdieping van die van het Maleis wijdde hij z'n beste krachten. Door verblijf in het Oosten en levendige interesse voor alles wat de in zijn tijd zo verwijde horizonten te aanschouwen boden was zijn belangstelling voor Oosterse talen en taalvergelijking gewekt. Zijn figuur is te belangrijk om vergeten te worden. 